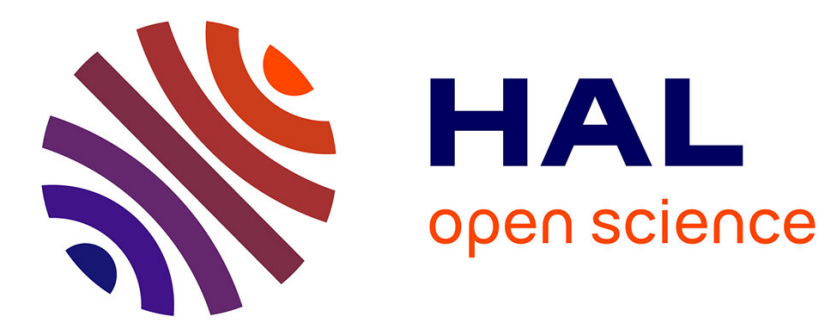

\title{
Growth and Memory effect of Ge in GaAs epilayers grown in UHV environment using IBGe
}

Alex Brice Poungoué Mbeunmi, Roxana Arvinte, Mohammad R. Aziziyan, Richard Arès, Simon Fafard, Abderraouf Boucherif

\section{- To cite this version:}

Alex Brice Poungoué Mbeunmi, Roxana Arvinte, Mohammad R. Aziziyan, Richard Arès, Simon Fafard, et al.. Growth and Memory effect of Ge in GaAs epilayers grown in UHV environment using IBGe. ICSI-ISTDM, Jun 2019, Wisconsin-Madison, United States. hal-02149995

\section{HAL Id: hal-02149995 \\ https://hal.science/hal-02149995}

Submitted on 11 Jun 2019

HAL is a multi-disciplinary open access archive for the deposit and dissemination of scientific research documents, whether they are published or not. The documents may come from teaching and research institutions in France or abroad, or from public or private research centers.
L'archive ouverte pluridisciplinaire HAL, est destinée au dépôt et à la diffusion de documents scientifiques de niveau recherche, publiés ou non, émanant des établissements d'enseignement et de recherche français ou étrangers, des laboratoires publics ou privés. 


\section{Growth and Memory effect of Ge in GaAs epilayers grown in UHV environment using IBGe}

\author{
Alex B. Poungoué M. \\ Interdisciplinary Institute for \\ Technological Innovation (3IT) \\ CNRS UMI-3463, Université de \\ Sherbrooke, Canada \\ Alex.Brice.Poungoue.Mbeunmi \\ @USherbrooke.ca
}

\author{
R. Arvinte \\ Interdisciplinary Institute for \\ Technological Innovation (3IT) \\ CNRS UMI-3463, Université de \\ Sherbrooke, Canada \\ ionela- \\ roxana.arvinte@usherbrooke.ca
}

A. Boucherif

Interdisciplinary Institute for

Technological Innovation (3IT)

CNRS UMI-3463, Université de

Sherbrooke, Canada

$\underline{\text { Abderraouf.Boucherif@USherbr }}$

ooke.ca

\author{
M. R. Aziziyan \\ Interdisciplinary Institute for \\ Technological Innovation (3IT) \\ CNRS UMI-3463, Université de \\ Sherbrooke, Canada \\ mohammad.reza.aziziyan@UShe \\ rbrooke.ca \\ S. Fafard \\ Interdisciplinary Institute for \\ Technological Innovation (3IT) \\ CNRS UMI-3463, Université de \\ Sherbrooke, Canada \\ Simon.Fafard@USherbrooke.ca
}

\author{
R. Arès \\ Interdisciplinary Institute for
Technological Innovation (3IT)
CNRS UMI-3463, Université de
Sherbrooke, Canada
Richard.Arès@USherbrooke.ca
}

\section{Abstract:}

The growth of Germanium (Ge) with iso-butyl germane (IBGe) as germanium source and the study of Ge memory effect in GaAs grown in UHV environment (Chemical beam epitaxy CBE reactor) is presented. High quality Ge epilayers were grown and a strong Ge memory effect was found in GaAs epilayers grown in the same reactor.

Keywords-UHV environment, Chemical Beam Epitaxy, IBGe, Germanium, memory effect, GaAs

\section{INTRODUCTION}

Germanium $(\mathrm{Ge})$ shows a great interest for optoelectronic and microelectronic technology. With its low band gap (0.66 $\mathrm{eV})$ and high absorption coefficient $\left(10^{4} \mathrm{~cm}^{-1}\right)$ in the wavelength range $1 \mu \mathrm{m}$ to $1.5 \mu \mathrm{m}$, Ge is very attractive for photovoltaic, infrared detection and thermophotovoltaic (TPV) conversion. Knowing that Ge has a lattice parameter similar to that of GaAs, $\mathrm{In}_{0.5} \mathrm{Ga}_{0.5} \mathrm{P}$ and AlGaAs, lattice matched epitaxial growth of heterostructures with minimal generation of dislocations can be carried out. This opens a wide range in the design and realization of new heterostructures for high efficiency solar cells for space and terrestrial applications [1]. In fact, high efficiency multijunction solar cells such as triple junction (TJ) based on lattice mismatched InGaP/InGaAs/Ge show nowadays a conversion efficiency beyond $40 \%$ [2]. In such a structure, Ge junction is used to convert the part of solar spectrum between 0.66 and $1.4 \mathrm{eV}$ [1]. The growth combination of $\mathrm{Si}_{\mathrm{x}} \mathrm{Ge}_{1-\mathrm{x}}$ with GaAs-based III-V compound semiconductor, introduces new opportunities for integration of III-V materials on silicon ( $\mathrm{Si}$ ) devices [3], such as solar cells and high-speed electronics [1]. In TPV devices, Ge sub cells are employed instead of GaSb and several research groups are working on developing new ways to reduce the TPV system cost by using Ge [1]. III-V multijunction solar cells require the growth of III-V structures usually on Ge substrates or even employing several $\mathrm{nm}$ of $\mathrm{Ge}$ as base cell. An easier approach will be the growth of solar cell structure, by group IV and III-V materials in the same reactor chamber. Such an approach was previously reported in literature for metalorganic vapor phase epitaxy (MOVPE) and molecular beam epitaxy (MBE) [3][4], displaying a strong Ge memory effect in III-V semi-conductor such as GaAs and limiting the growth of high quality III-V layers. In this study, we investigate the growth of Ge by isobutyl germane (IBGe) as Ge source on GaAs substrates under ultra-high vacuum (UHV) environment. An important interest was given to the Ge growth and study of the memory effect of $\mathrm{Ge}$ in GaAs epilayer in the reactor chamber. High resolution Xray diffraction (HR-XRD) were carried out to study the structural properties of grown Ge and III-V layers. The Ge background doping was determined by Hall effect measurements.

\section{RESULTS AND DISCUSSION}

\section{A. Approach}

The epitaxial growth was carried out in a VG Semicon VG90H Chemical Beam epitaxy (CBE) reactor equipped with IBGe as Ge source, high purity (6N5) thermally cracked $\mathrm{AsH}_{3}$ and triethylgallium (TEGa) as arsenic and gallium sources, respectively. Semi insulating GaAs (S-I GaAs) were used as substrates for the growth of Ge and GaAs layers.

\section{B. Growth of Ge on S-I GaAs}

To confirm the crystalline structure of the grown $\mathrm{Ge}$ layers, HR-XRD measurements have been performed. Fig. 1 shows the X-ray rocking curve of the symmetrical (004) reflection. It can be noticed the presence of two peaks attributed to Ge epilayer and GaAs substrate. Moreover, the appearance of Pendellösung fringes indicates a high crystalline 
quality and good interface between Ge and GaAs. Based on these fringes a $\sim 620 \mathrm{~nm}$ thick Ge epilayer was calculated which agrees with the thickness obtained by secondary electron microscopy (SEM).

\section{Growth of GaAs on S-I GaAs}

Fig. 2 displays the HR-XRD rocking curve obtained on GaAs epilayer before the use of Ge source and after. We can notice that the crystalline structure of GaAs layer before and after Ge remains similar. Therefore, the impact of $\mathrm{Ge}$ at the structural level remains unnoticeable.

In our UHV chamber the background doping in GaAs was found to be in the range $5 \times 10^{15}$ to $1 \times 10^{16} \mathrm{~cm}^{-3}$ (with holes as majority carriers) when no Ge source was used. Since the memory effect is an expected consequence of using Ge source in the same chamber, Hall effect measurements on GaAs epilayers were carried out. Therefore, we have found that the background doping in the reactor chamber increased up to 5.5 $\times 10^{18} \mathrm{~cm}^{-3}$ with electrons as majority carriers. This can be explained by the fact that Ge acts as donor in GaAs [3]. Such a strong memory effect of Ge limits the growth of III-V heterostructures for solar cells. To reduce the strong $\mathrm{Ge}$ memory effect in our reactor, various methods are under study. An annealing of the reactor under $\mathrm{AsH}_{3}$ flow showed a Ge background doping decrease up to $1 \times 10^{18} \mathrm{~cm}^{-3}$. This result seems encouraging and additional methods to reduce further the memory effect are under study.

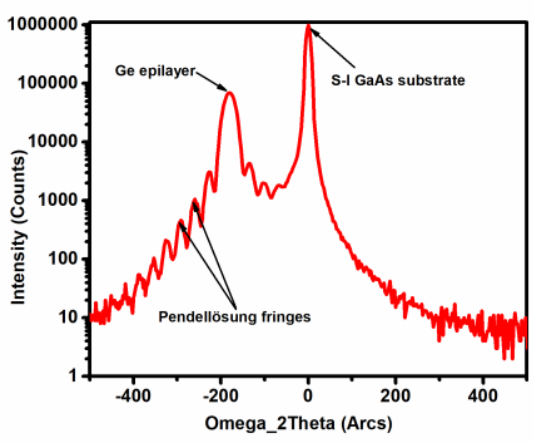

Fig. 1. HR-XRD rocking curve of (004) reflection of Ge/GaAs structure

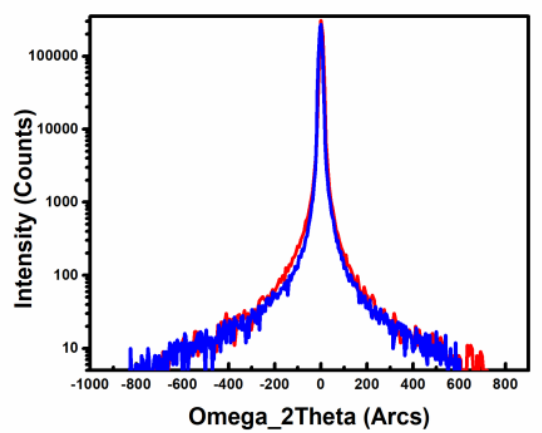

Fig. 2. (Color online) HR-XRD rocking curve of (004) reflection of $\mathrm{GaAs} / \mathrm{GaAs}$ structure, before (Red) and after (Blue) employ of Ge source

\section{CONCLUSION}

The growth of Ge in UHV environment was studied indicating a high crystalline quality of Ge epilayers grown on GaAs substrates. Hall effect measurements have shown a strong memory effect of $\mathrm{Ge}$ in GaAs, with a background doping in the range $5.5 \times 10^{18} \mathrm{~cm}^{-3}$. To decrease this high background doping in our $\mathrm{CBE}$ reactor, different methods are under study. An annealing under $\mathrm{AsH}_{3}$ flow lead to a small reduction of $\mathrm{Ge}$ background doping in GaAs in the range $1 \times$ $10^{18} \mathrm{~cm}^{-3}$. These results are highly interesting for photovoltaic applications.

[1] M. Bosi and G. Attolini, "Germanium: Epitaxy and its applications," Prog. Cryst. Growth Charact. Mater., vol. 56, no. 3-4, pp. 146-174, 2010.

[2] G. Attolini et al., "MOVPE growth of homoepitaxial germanium," $J$. Cryst. Growth, vol. 310, no. 14, pp. 3282-3286, 2008.

[3] E. Welser, W. Guter, A. Wekkeli, and F. Dimroth, "Memory effect of Ge in III-V semiconductors," J. Cryst. Growth, vol. 310, no. 23, pp. 4799-4802, 2008.

[4] C. G. N. Publishing, C. Academ, C.- Mellon, and C. Pennsylvania, "The residual effects of germanium as an n-type dopant for GaAs during Molecular Beam Epitaxial growth,” vol. 62, pp. 95-105, 1983. 